\title{
VARIOUS METHODS FOR CALCULATING THE WATER QUALITY INDEX
}

Article DOI: https://doi.org/10.35219/ann-ugal-math-phys-mec.2018.2.09

\author{
Valentina-Andreea Călmuc ${ }^{1 *}$, Mădălina Călmuc ${ }^{1}$, Maria Cătălina Țopa ${ }^{1}$, \\ Mihaela Timofti ${ }^{1}$, Cătălina Iticescu ${ }^{1}$, Lucian P. Georgescu ${ }^{1}$ \\ 1 "Dunarea de Jos" University of Galati, European Center of Excellence for the Environment, Faculty of \\ Sciences and Environment, 111 Domneasca Street, 800201, Galati, Romania. \\ *Corresponding author: valentinacalmuc@yahoo.ro;
}

\begin{abstract}
At present, the most commonly used method to evaluate the quality of a water stream is the application of the Water Quality Index, which may be determined by using different methods. The main purpose of this study is to describe four methods for calculating the Water Quality Index with their advantages and disadvantages: NFS-WQI (National Sanitation Foundation-Water Quality Index), OWQI (Oregon Water Quality Index), WAWQI (Weighted Arithmetic Water Quality Index) and CCME-WQI (Canadian Council of Ministers of the Environment -Water Quality Index). Choosing one of the four methods mentioned above should be based on the study purpose and on the nature of the water stream. These indices have already been used to determine the quality of the Danube water in the all the riverine states. Moreover, the present research reveals that two methods are proved to be useful in determining the Danube water quality, namely: WAWQI (Weighted Arithmetic Water Quality Index) and CCME-WQI (Canadian Council of Ministers of the Environment -Water Quality Index).
\end{abstract}

Keywords: Water Quality Index, NFS-WQI, OWQI, WAWQI, CCME-WQI, Danube.

\section{INTRODUCTION}

The Water Quality Index represents a numerical expression which has the purpose of establishing the ecological state of a body of water [1-3]. For the general calculation of this index, it is usually necessary to determine the following physical, chemical and biological parameters: temperature, the $\mathrm{pH}$, the electrical conductivity, dissolved oxygen, the total dissolved solids (TDS), alkalinity, the biochimic consumption of oxygen (CBO), the chemic consumption of oxygen (CCO), nitrogenous $\left(\mathrm{NO}^{3-}\right.$, nitrites, ammonium (NH4+), clorides, metals $\left(\mathrm{Cr}\right.$-total, $\mathrm{Pb}^{2+}, \mathrm{Cd}^{2+}, \mathrm{Ni}^{2+}, \mathrm{Fe}^{-}$total, Mn-total, $\mathrm{Zn}^{2+}, \mathrm{As}^{2+}$ ) and hardness [4-7]. This method does not usually limit the concomitant calculation of all physicochemical and biological parameters together, they also can be calculated separately. It is very important to consider, when using this method, the variation of physico-chemical parameters which exists mostly due to the anthropic factors, but also due to natural processes such as the hydrological, topographical, litholology, climate, the hydrographic basin, geological rocks and, last but not least, to erosion [8]. According to the resulting value obtained by the calculation of the WQI index, the water samples to be studied could be framed in one of the following water quality categories: excellent, good, poor, very poor, undrinkable [ 1, 7, 9-11].

The WQI index was first developed in the United States in 1965 by Horton [12]. Since then, more methods of calculus have been invented to obtain the same water quality index (WQI) [13]. This is mainly based on the different approach regarding the selection of parameters and on their influence on the calculation and final value of the indexes [8]. In 1970, the NFS-WQI index was developed by Brown and the collaborators. This represents a better version of Horton's index [11, 14]. Also, the 
Environment Department of Oregon implemented in 1970 the Oregon Water Quality Index (OWQI) [15] while Canada introduced the CCME WQI Index - Canadian Council of Ministers of the Environment Water Quality Index - in 1990 [8]. Another method for determining the water quality index is the Weighted Arithmetic Water Quality Index Method (WAWQI), which is more appropriate than other methods due to its factoring upon more quality parameters within one main mathematical equation, as well as to its possibility to describe the quality of surface and underground waters [13].

National and international organisations of different states have developed more types of water quality indexes depending on their need to evaluate the level of water quality in a specific area of interest. Up to the present, specialists have not suggested any stable method for the water quality evaluation which could be used worldwide. Moreover, no method of water quality evaluation offers $100 \%$ objectivity and accuracy [8].

The main goal of this paper is to present the four most common methods for calculating the WQI and the usefulness degree of these methods in the studies evaluating the surface water quality in the hydrographic basin of the Danube.

\section{WQI CALCULATION METHODS}

2.1. NSF-WQI (National Sanitation Foundation-Water Quality Index) includes the following nine parameters of quality: TDS (total of dissolved solids), $\mathrm{pH}$, turbidity, phosphates, nitrates, CBO5 (biochemical consumption of oxygen), Coliforms, OD (dissolved oxygen), temperature [14, 16-18]. As each parameter presents a different contribution upon the modification of the water quality, a specific weight in the calculation of the NFS-WQI index was attributed to each of these, as presented in Table $1[16,17,20]$. This index is calculated based on formula 1.

\section{(1) $\mathrm{NSF}-\mathrm{WQI}=\sum_{i=1}^{n} \mathrm{~W} i \mathrm{Q} i$}

where: WQI-NFS is a numerical value between $0-100$; Wi is the weighting factor for each parameter (Tabel1); Qi is the sub-index of the quality parameter $\mathrm{i}$, which is obtained from the conversion curve (curves that convert parameters determined by values from the interval 0-100) [18-20].

According to the value obtained by calculating the NFS-WQI index, the analyzed body of water frames in one of the five categories presented in Table 2.

Table 1: Weight scores of the nine NSF-WQI parameters

\begin{tabular}{|c|c|}
\hline Parameter & Weight \\
\hline Dissolved oxygen (OD) & 0.17 \\
\hline Coliforms & 0.16 \\
\hline $\mathrm{pH}$ & 0.11 \\
\hline Biochemical oxygen demand (BOD) & 0.11 \\
\hline Temperature & 0.1 \\
\hline Nitrates & 0.1 \\
\hline Total phosphate & 0.1 \\
\hline Turbidity & 0.08 \\
\hline Total solids (TDS) & 0.07 \\
\hline
\end{tabular}

Table 2: Water quality value (NFS -WQI)

$[17,20]$

\begin{tabular}{|c|c|}
\hline Value- NFS -WQI & Water Quality \\
\hline $90-100$ & Very good \\
\hline $70-90$ & Good \\
\hline $50-70$ & Medium \\
\hline $25-50$ & Bad \\
\hline $0-25$ & Very bad \\
\hline
\end{tabular}


Advantages:

- It sums up the data referring to the analyzed parameters within only one value, in a fast, objective manner which is also reproducible;

- The evaluation of water quality changes in different areas;

- The index value indicates the potential water use.

Disadvantages:

- It does not utilize a complex scale of water quality parameters;

- Some of the data get lost while being manipulated [21,22].

2.2. OWQI (Oregon Water Quality Index) is used to describe the quality of surface waters bodies from Oregon, as well as from other geographical areas. The eight physical, chemical and biological parameters used in this descriptive method for the water quality are: temperature, dissolved oxygen (OD), biochemical oxygen demand (BOD), $\mathrm{pH}$, ammonia+nitrate nitrogen, total phosphorus, total dissolved solids (TDS) and Coliforms [15, 21]. This index was suggested starting from the model of NSF-WQI. The difference lies in the calculus method and in the weight of the parameters which is not even taken into consideration in this case. The mathematical expression for this method utilizes the concept of arithmetical average and it is given by formula 2 [21].

$$
\text { (2) } \mathrm{OWQI}=\sqrt{\frac{\mathrm{n}}{\sum_{\mathrm{i}=1 \frac{1}{\mathrm{SIi}^{2}}}^{2}}}
$$

where: $\mathrm{n}$ is the numbers of parameters $(\mathrm{n}=8)$, and $\mathrm{Si}$ is the sub-index of sub-index ith parameter [19, $21,23]$. The calculus method of the sub-index for each parameter is presented in much more detail in Cude's article, 2001.

The obtained value after the index calculation of the water utilizing the Oregon Water Quality Index method indicates the quality of the analyzed water, as shown in Table 3 below:

Table 3: The corresponding values to water quality in conformity with OWQI $[19,21]$

\begin{tabular}{|c|c|}
\hline OWQI Value & Water Quality \\
\hline $90-100$ & Excellent \\
\hline $85-89$ & Good \\
\hline $70-84$ & Fair \\
\hline $60-70$ & Poor \\
\hline $59-0$ & Very poor \\
\hline
\end{tabular}

Advantages:

- The utilization of weighted harmonic to combine sub-indexes enables the most impacted parameters to influence the OWQI the most;

- The formula is sensitive to environmental changes and significant impacts on water quality.

Disadvantages:

- It cannot provide definitive information regarding changes in toxics concentrations, habitat or biology;

- It cannot evaluate all the toxic elements for health (bacteria, metal, toxics) [21,22].

2.3. Weighted Arithmetic Water Quality Index Method provides information regarding the quality evaluation of a body of water. This method uses the most commonly measured water quality 
parameters (pH, BOD, COD, DO, $\mathrm{P}-\mathrm{PO}_{4}{ }^{3-}, \mathrm{N}-$ total, $\mathrm{N}-\mathrm{NO}^{3-,} \mathrm{N}-\mathrm{NO}^{2--} \mathrm{N}-\mathrm{NH}^{4+}, \mathrm{SO}_{4}{ }_{4}^{2-}, \mathrm{Cl}$, Cr-total, $\mathrm{Pb}^{2+}$, $\mathrm{Cd}^{2+}, \mathrm{Ni}^{2+}, \mathrm{Fe}$-total, Mn-total, $\left.\mathrm{Zn}^{2+}, \mathrm{As}^{2+}\right)[5,24]$ and it is calculated according to the following formula (3):

$$
\text { (3) WAWQI }=\frac{\Sigma W i q i}{\Sigma W i}
$$

where: WQI has a value between 0 and 100 which indicates the quality of the water; qi represents a relative value of the water quality, specific to each parameter; i represents the number of parameters taken into consideration; $\mathrm{Wi}$ is a factor which measures the importance of a parameter in the calculation of the WQI index (relative weight); qi is calculated by applying formula 4 below:

$$
\text { (4) } \mathrm{Q}_{\mathrm{i}}=100 * \frac{V i-V 0}{S i-V 0}
$$

where: Vi represents the value experimentally determined of the i analyzed parameter; V0 represents the ideal value of that parameter; Si represents the standard, legally accepted, value for the water category in which the analyzed water sample was included. Wi factor is calculated by using formula 5 :

$$
\text { (5) } \mathrm{W}_{\mathrm{i}}=\frac{\mathrm{K}}{\mathrm{Si}}
$$

where $\mathrm{K}$ is a constant which can result from applying formula 6 [24-26].

$$
\text { (6) } \mathrm{K}=\frac{1}{\sum\left(\frac{1}{\mathrm{Si}}\right)}
$$

Based on the value obtained for the Weighted Arithmetic WQI method, the water ecological status may be determined, as illustrated by Table 4 .

Table 4: Water Quality Rating as per Weight Arithmetic Water Quality Index Method $[21,22,24]$

\begin{tabular}{|c|c|}
\hline WQI Value & Water quality \\
\hline $0-25$ & Excellent \\
\hline $26-50$ & Good \\
\hline $51-75$ & Poor \\
\hline $76-100$ & Very Poor \\
\hline$>100$ & Unsuitable for drinking \\
\hline
\end{tabular}

Advantages:

- It encompasses the values of various physico-chemical parameters of water quality into a mathematical equation, which indicates the water ecological state;

- It reflects the importance that each parameter has in the evaluation and management of water quality

- It can be used to describe the suitability of both surface and underground water sources for human consumption.

Disadvantages:

- This index may not provide enough information about the real situation of the water quality;

- This index does not include all the parameters which can describe the quality of a body of water [21, 22];

- This index only quantifies the direct effect of pollution on a body of water. 
2.4. The Canadian Council of Ministers of the Environment Index (CCME-WQI) utilizes the following parameters for determining the water quality in a stream: temperature, conductivity, color, turbidity, dissolved oxygen (OD), $\mathrm{pH}$, alkalinity, $\mathrm{Ca}, \mathrm{Na}, \mathrm{Mg}, \mathrm{K}, \mathrm{SO} 4, \mathrm{Cl}-$, F-, Dissolved Organic Carbon, P, Nitrates, Nitritis, N, $\mathrm{SiO}_{2}$, Al, As, Ba, Be, Cd, Co, Cr, Cu, Fe, Hg, Li, Mn, Mo, Ni, Pb, Se, $\mathrm{Sr}, \mathrm{V}, \mathrm{Zn}$ [27]. This is calculated by using three main factors, F1, F2, F3, which can be deducted directly through by applying some formulas.

$F_{1}$ (How many?) is the factor which represents the percentage of variables which do not meet the objectives (referential values) at least once during the period (failed variables) and they are usually calculated by using formula 7 .

(7) $\mathrm{F}_{1}=\left(\frac{\text { Number of failed variables }}{\text { Total number of variables }}\right) * 100$

$\mathrm{F}_{2}$ (How often?) is the factor representing the percentage of individual tests which do not meet the goals at all (failed tests).

(8) $\mathrm{F}_{2}=\left(\frac{\text { Number of failed test }}{\text { Total number of tests }}\right)^{*} 100$

$F_{3}$ (How much?) is the factor which represents the amount through which the test values did not respect their guideline values. This is calculated in three steps:

a. When the test value must not exceed the objective:

(9) excursion $_{i}=\left(\frac{\text { Failed Test Value }}{\text { Objective }}\right)-1$

b. When the test value must not fall below the objective:

(10) excursion $_{i}=\left(\frac{\text { objective }}{\text { Failed Test Value }}\right)-1$

c. The collective amount of excursions which are out of compliance is calculated according to the following formula:

(11) $\mathrm{nse}=\frac{\sum_{i=1}^{n} \text { excursion }}{\text { number of tests }}$

(12) $\mathrm{F}_{3}=\left(\frac{n s e}{0.01 n s e+0.01}\right)$

After determining all these factors, the Canadian Council of Ministers of the Environment Index (CCME-WQI) may be calculated according to formula 13 [21, 29, 30].

(13) $\mathrm{CWQI}=100-\left(\frac{\sqrt{F 1^{2}+F 2^{2}+F 3^{2}}}{1.732}\right)$

The value obtained by calculating the index in compliance with the above presented formulas may frame the analyzed water in one of the specific quality categories included in Table 5.

Table 5: The corresponding values of water quality in conformity with CCME-WQI Index $[22,29,30]$

\begin{tabular}{|c|c|}
\hline CCME-WQI-Value & Water quality \\
\hline $95-100$ & Excellent \\
\hline $80-94$ & Good \\
\hline $60-79$ & Fair \\
\hline
\end{tabular}




\begin{tabular}{|c|c|}
\hline $45-59$ & Marginal \\
\hline $0-44$ & Poor \\
\hline
\end{tabular}

Advantages:

-It has a high adaptability to different water uses

-Easy to calculate

-It has a low level of sensibility to the case of missing data.

-It is appropriate for analyzing data coming from automated sampling.

Disadvantages

- All the variables have the same importance in the determination of the index.

- It cannot be mixed up with other indicators or with other biological data.

- The water quality gets described only partially.

- $\mathrm{F}_{1}$ does not work appropriately when too few variables are taken into consideration [21, 22].

\section{CONCLUSIONS}

In order to establish water quality at a general level, a variety of methods for determining the water quality index have been suggested. Studies of great diversity have been made on this topic and the values obtained by using a specific method for water quality evaluation have proved important and useful.

Studies made on the Danube in the past years [5] used the water quality index calculated by using the Weighted Arithmetic Water Quality Index Method. This method enables the inclusiveness of various physicochemical parameters, aspect which favours obtaining more accurate results meant to provide relevant information about the actual quality of the Danube water. According to Iticescu et al. (2013) the values obtained for the WQI were situated between 39.01 (during winter) and 65.21 (during autumn), varying from a season to another and from a sampling station to another, depending on the polluting source(s). The main sources of pollution upon the Danube affecting the analyzed sector from this study are: the ore port, the agricultural activities (fertilizers based on nitrogen and phosphorus) and wastewater. It was concluded that this index successfully includes a group of physico-chemical parameters, among which its sensibility to cadmium. This metal produces variations in the final values of the WQI.

Furthermore, the Canadian Council of Ministers of the Environment Index (CCME-WQI) was used for determining the quality of the Danube, in a study made in Serbia in 2010. This index comes with the advantage of providing information regarding the pollution level with heavy metals. Moreover, it can also evaluate the water quality from a general perspective, as well as from the point of view of its utilization: for drinking, for the aquatic environment, for amusement or for irrigations. The general values of the CWQI index range between 51-77, the water quality on the Serbian sector being fair and marginal [27].

The choice of the final method for determining the quality of the water stream from the point of view of the physical-chemical water quality indexes depends on their nature and complexity, as well as on the purpose of their calculation.

Acknowledgement: This work was supported by the project "Strategy and actions for preparing the national participation in the DANUBIUS-RI Project" acronym "DANS" financed by the Romanian Ministry of Research and Innovation.

\section{References}

1. Ismail A., Robescu L. D., Chemical water quality assessment of the Danube river in the lower course using water quality indices, U.P.B. Sci. Bull., Series B. 79, 51-61, 2017. 
2. Effendi H., Romanto Wardiatno Y., Water Quality Status of Ciambulawung River, Banten Province, Based on Pollution Index and NSF-WQI, Procedia Environ Sci . 24, 228-237, 2015,

3. Gazzaz N. M., Yusoff M. K., Aris A., Z., Juahir H., Ramli M. F., Artificial neural network modeling of the water quality index for Kinta River (Malaysia) using water quality variables as predictors, Marine Pollution Bulletn. 64, 2409-2420, 2012.

4. Sharma P., Meher P.K., Kumar A., Gautam Y.P., Mishra K.P., Changes in Water Quality Index of Ganges River at Different Locations in Allahabad, Water Network Research. 73 (10), 2413-2420, 2014.

5. Iticescu C., Georgescu L. P., T,opa C. M., Assessing the Danube water quality index in the city of Galati, Romania, Carpath. J. Earth Environ. Sci. 8, 155-164, 2013.

6. Stoica C., Camejo J., Banciu M., Nita-Lazăr M., Păun S., Cristofor O. R., Guevara M., Water quality of Danube Delta systems: ecological status and prediction using machine-learning algorithms, Water Science \& Technology. 2415-2416, 2016.

7. Boah D. K., Twum S. B., Pelig-Ba K. B., Mathematical Computation of Water Quality Index of Vea Dam in Upper East Region of Ghana, Environmental Sciences. 3(1), 11-16, 2015.

8. Uddin M. G., Moniruzzaman M., Khan M., Evaluation of Groundwater Quality Using CCME Water Quality Index in the Rooppur Nuclear Power Plant Area, Ishwardi, Pabna, Bangladesh, American Journal of Environmental Protection, 5 (2), 33-43, 2017.

9. Chowdhury R.M., Muntasir S.Y., Hossain M.M, Water Quality Index of water bodies along Faridpur-Barisal Road in Bangladesh, Glob. Eng. Tech. Rev. 2, 1-8, 2012.

10. Teodorof L., Burada A., Despina C., Seceleanu-Odor D., Tudor A. I.-M., Ibram O., Navodaru I., Tudor M, Integrated indices for surface water and sediment qualit, according to Water Framework Directive, J ENVIRON PROT ECOL. 17, 42-52, 2016.

11. Lumb A., Sharma T.C., Bibeault J.-F. A, Review of Genesis and Evolution of Water Quality Index(WQI) and Some Future Directions, Water Qual. Expo. Health. 3, 11-24, 2011.

12. Bordalo A. A., Nilsumranchit W., Chalermwat K., Water Quality And Uses Of The Bangpakong River (Eastern Thailand), Water Research. 35 (15), 3635-3642, 2001.

13. Chandra D. S., Asadi S. S., Raju M. V. S., Estimation of Water Quality Index by Weighted Arithmetic Water Quality Index Method: A Model Study, International Journal of Civil Engineering and Technology (IJCIET). 8 (4), 1215-1222, 2017.

14. Ichwana I., Syahrul S., Wirda N., Water Quality Index by Using National Sanitation Foundation-Water Quality Index (NSF WQI) Method at Krueng Tamiang Aceh, International Conference on Technology, Innovation and Society (ICTIS). 110-117, 2016.

15. Cude C. G., Oregon Water Quality Index a tool for evaluating water quality management effectiveness, Journal Of The American Water Resources Association. 37 (1), 125-137, 2001.

16. Mihăiescu T., Mihăiescu R., Vârban D., Vârban R., Mihăiescu M., Analele Universităţii din Oradea, Fascicula Protecţia Mediului. 11, 649-654, 2013.

17. Ewaid S. H., Water quality evaluation of Al-Gharraf river by two water quality indices, Applied Water Science. 7, 3759-3765, 2017.

18. Samadi M. T., Sadeghi S., Rahmani A., Saghi M. H., Survey of water quality in Moradbeik river basis on WQI index by GIS, Environmental Health Engineering and Management Journal. 2 (1), 7-11, 2015.

19. Darvishi G., Kootenaei F. G., Ramezani M., Lotfi E., Asgharnia, H., Comparative Investigation of River Water Quality by OWQI, NSFWQI and Wilcox Indexes (Case study: the Talar River - IRAN), Archives of Environmental Protection. 42 (1), 41-48, 2016.

20. Behmanesh A., Assessment the water quality of Babolrood river based on the NSF Water Quality Index, International Journal of Biology, Pharmacy, Allied Sciences (IJBPAS). 4 (5), 342-352, 2015.

21. Tyagi S., Sharma B., Singh P., Dobhal R., Water Quality Assessment in Terms of Water Quality Index, American Journal of Water Resources. 1 (3), 34-38, 2013. 
22. Paun I., Cruceru L. V., Chiriac F. L., Niculescu M., Vasile G. G., Marin N. M., Water Quality Indices - Methods For Evaluating The Quality Of Drinking Water, National Research and Development Institute for Industrial Ecology, INCD-ECOIND. 395-402, 2016.

23. Tirkey P., Bhattacharya T., Chakraborty S., Water Quality Indices- Important Tools for Water Quality Assessment: A Review. IJAC. 1, 15-29, 2015.

24. Oni O., Fasakin O., The Use of Water Quality Index Method to Determine the Potability of Surface Water and Groundwater in the Vicinity of a Municipal Solid Waste Dumpsite in Nigeria, AJER. 5, 96-101, 2016.

25. Khwakaram A. I, Majid S. N., Hama N.Y, Determination of Water Quality Index (WQI) for Qalyasan Stream in Sulaimani City/ Kurdistan region of Iraq, IJPAES . 2, 148-157, 2012.

26. Akoteyon I.S., Omotayo A.O., Soladoye, O., Olaoye H.O, Determination of Water Quality Index and Suitability of Urban River for Municipal Water Supply in Lagos-Nigeria, Eur. J. Sci Res. 54, 263-271, 2011.

27. Jakovljevic D., Serbian And Canadian Water Quality Index Of Danube River In Serbia in 2010, J. Geogr. Inst. Cvijic. 62, 1-18, 2012.

28. Fataei E., Seyyedsharifi S. A., Seiiedsafaviyan, S.T., Nasrollahzadeh, S., Water Quality Assessment Based on WQI and CWQI Indexes in Balikhlou River, Iran. J. Basic. Appl. Sci. Res. 3, 263-269, 2013.

29. Lumb, A., Halliwell, D., Sharma, T., Application of CCME water Quality Index to monitor Water Quality: a case of the Mackenzie River basin, Canada, Environ Monit Assess. 113, 411429. 2006.

30. Mahagamagea, M. G. Y. L., Managea, P.M. Water Quality Index (CCME-WQI) Based Assessment Study of Water Quality in Kelani River Basin, Sri Lanka, Environ. Nat. Resource. J. 12, 199-204, 2014.

31. Uddin M.G., Moniruzzaman M., Khan M, Evaluation of Groundwater Quality Using CCME Water Quality Index in the Rooppur Nuclear Power Plant Area, Ishwardi, Pabna, Bangladesh, AJEP. 5, 33-43, 2017. 